\title{
The anaesthetic management of neuro- surgical emergencies
}

Rosemary A. Craen MB BS FFARACS, Adrian W. Gelb MB ChB FRCPC
TABLE I Neurosurgical emergencies

The most common neurosurgical emergency requiring the special skills of an anaesthetist is the head-injured patient (Table I). This lecture will therefore focus mainly on the anaesthetic management of head injuries but it should be borne in mind that the principles of management apply equally well to other neurosurgical emergencies associated with elevated intracranial pressure (ICP).

\section{Head injuries}

Head injuries are a major cause of death among people under the age of $30 \mathrm{yr}$ and result in more than 200,000 potential years of lost life in Canada each year. ${ }^{1}$ Motor vehicle accidents (MVA) are the most frequent cause of head trauma accounting for about $45 \%$ of all cases. ${ }^{2}$ Although more than $50 \%$ of patients with head injuries will have extracranial injuries as well, it is the head injury that is the main cause of death in $68 \%$ of MVA victims. ${ }^{2,3}$

\section{Pathophysiology of head injury}

Injury to the brain occurs in two phases. At the moment of impact, a variable amount of primary brain injury occurs. This is usually irreversible. Then, secondary processes are set in motion which lead to further brain injury and often death. At the present time, we have preventative but not therapeutic measures for primary brain injury. All our therapy is directed at the secondary insult. The primary brain injury represents a continuum of injury (Table II). Mild injuries tend to involve only the cortex while progressively more severe injuries involve the deeper structures including the brainstem. Even the mildest of injuries can be associated with brain damage; patients who are neurologically intact may demonstrate evidence of cortical injury on magnetic resonance imaging. ${ }^{4}$

The changes of secondary brain injury (Table III) when superimposed on the initial cerebral insult have a major impact on the outcome of head-injured patients. ${ }^{5}$ If the patient reaches hospital alive, then, theoretically, treatment or prevention of the secondary injury should prevent death. In a review of avoidable factors in the death of head-injured patients who talked after injury, $26 \%$ had an airway obstruction, $22 \%$ had hypotension, and $17 \%$ had poorly controlled seizures. ${ }^{6}$ The anaesthetist has the technical skills and the knowledge of physiology and pharmacology to make a major contribution to the wellbeing of these patients.

\begin{tabular}{|c|c|}
\hline $\begin{array}{l}\text { Lesions: } \\
\begin{aligned} & \text { Trauma }- \text { Skin, muscle } \\
&- \text { Bone } \\
&- \text { Vessels } \\
&- \text { Brain } \\
& \text { Mass }- \text { Blood } \\
&- \text { Pus } \\
&- \text { Tumour } \\
&- \text { CSF } \\
& \text { Vascular occlusion }\end{aligned}\end{array}$ & $\cdot$ \\
\hline TABLE II Primary brain & jury \\
\hline \begin{tabular}{|l} 
Amnesia \\
Concussion \\
Contusion \\
Laceration \\
Diffuse axonal injury \\
Instant death
\end{tabular} & A continuum \\
\hline
\end{tabular}

TABLE III Causes of secondary brain injury

\begin{tabular}{ll}
\hline Systemic & Intracranial \\
\hline Hypoxaemia & Haematoma \\
Hypotension & Oedema \\
Anaemia & Hydrocephalus \\
Hypercarbia & Epilepsy \\
Hyperthermia & \\
\hline
\end{tabular}

Factors influencing intracranial pressure

The intracranial space may be regarded as a rigid container of almost constant volume consisting of brain (85\%), blood (5\%) and cerebrospinal fluid (CSF) (10\%). In head trauma, intracranial volume is most commonly increased by haematoma or oedema formation. This increase in volume of one constituent must be compensated by a reduction in volume of the other constituents. Initially, CSF is displaced out of the cranium into the distensible spinal subarachnoid space. Some additional compensation is provided by increased CSF absorption. Blood is also displaced from intracranial veins and sinuses into the jugular veins and spinal epidural veins. Lastly, the brain is

From the Department of Anaesthesia, University of Western Ontario, London, Canada. 
TABLE IV Treatment of intracranial hypertension

\begin{tabular}{lll}
\hline Fast & Intermediate & Slow \\
\hline Hyperventilation & Mannitol & Surgery \\
Thiopentone & Furosemide & Hypothermia \\
Muscle relaxants & Head up & Fluid restriction \\
$\begin{array}{l}\text { External drainage of CSF } \\
\text { Other sedatives }\end{array}$ & $\downarrow$ BP & \\
\hline
\end{tabular}

shifted away from the mass, either from one side to the other, or from one compartment to the other through the tentorial notch. These volume buffering mechanisms work well initially and ICP changes very little. Eventually, the compensatory mechanisms fail. As ICP rises, a very small increase in intracranial volume will lead to a marked increase in ICP. The clinical importance of raised ICP is two-fold. First, the cerebral perfusion pressure (CPP), which is the difference between mean arterial pressure (MAP) and ICP, is decreased until a critical point at which ischaemia is produced. Second, the brain shifts which compensate for volume change compress vascular structures inducing ischaemia and brain death.

Raised ICP may be treated in various ways (Table IV). Arterial $\mathrm{PaCO}_{2}$ is a potent physiological modulator of cerebral blood flow (CBF) and cerebral blood volume (CBV). CBV changes about $0.04 \mathrm{ml} \cdot 100 \mathrm{~g}^{-1}$ perfused tissue for each $\mathrm{mmHg}$ change in arterial $\mathrm{PaCO}_{2}$ over the range of $20-80 \mathrm{mmHg}{ }^{7}$ In the average brain $(1400 \mathrm{~g})$, this amounts to $0.56 \mathrm{ml} \cdot \mathrm{mmHg} \mathrm{PaCO}_{2}{ }^{-1}$. A reduction in $\mathrm{PaCO}_{2}$ from $45 \mathrm{mmHg}$ to $25 \mathrm{mmHg}$ will therefore reduce CBV by about $11 \mathrm{ml}$. This small volume may be important if the patient is on the genu of the intracranial compliance curve. Acute hyperventilation has a rapid effect, making it a first choice in the treatment of raised ICP. Hyperventilation, with its propensity to vasoconstriction, may have an adverse effect by reducing CBF. Reduced CBF and cerebral metabolic rate $\left(\mathrm{CMRO}_{2}\right)$ are frequently present in patients with head trauma and these patients may not benefit from the additional vasoconstriction. ${ }^{8}$ However, by contrast, in some patients, particularly children, the phenomenon of acute hyperaemia occurs giving rise to raised ICP and diffuse brain swelling which may respond to hyperventilation. ${ }^{8.9}$ Unfortunately, it is not possible to predict the patients with critically low CBF on the basis of clinical signs or $\mathrm{CT}$ scans. ${ }^{10}$ Cerebral venous $\mathrm{O}_{2}$ saturation may be useful to determine the optimal level of hypocapnia as inadequate global CBF will give a widened arteriovenous $\mathrm{O}_{2}$ content difference. ${ }^{8}$

Brain injury impairs the normal cerebrovascular responses to blood pressure, $\mathrm{O}_{2}$, and $\mathrm{CO}_{2} \cdot{ }^{11}$ Autoregulation is often impaired first, followed by the hypoxic response and then the loss of $\mathrm{CO}_{2}$ reactivity. ${ }^{11}$ In these areas of impaired autoregulation, $\mathrm{CBF}$ will vary passively with the MAP/CPP. Thus pressures that are normally associated
TABLE $V$ The effect of drugs on ICP

\begin{tabular}{lll}
\hline Decrease & No change & Increase \\
\hline Thiopentone & Vecuronium & Ketamine \\
Propofol & Atracurium & Succinylcholine \\
Benzodiazepines & Pancuronium & D-tubocurarine \\
Narcotics & $\mathrm{N}_{2} \mathrm{O} \pm$ Suppl. Anaes. & Nitrous oxide \\
Droperidol & Labetatol & Isoflurane \\
& Beta-blockers & Halothane \\
& & Nitroglycerin \\
& & Nitroprusside \\
& & Hydralazine \\
\hline
\end{tabular}

with unchanged $\mathrm{CBF}$ may result in critical ischaemia or dramatic increases in ICP. Fortunately, $\mathrm{CO}_{2}$ reactivity is not abolished until late and its loss is a bad prognostic indicator. $^{8}$

\section{Effect of drugs}

The effect of various drugs on intracranial pressure is shown in Table V.

\section{THIOPENTONE}

Thiopentone is still the induction agent of choice in the head-injured patient because it produces a dose-dependent reduction in CBF and ICP. However, the induction dose must be titrated in small repeated doses to avoid a catastrophic reduction in blood pressure in the hypovolaemic patient. The effectiveness of thiopentone as a cerebral protective drug in head injury has not been established. ${ }^{12}$

\section{PROPOFOL}

In patients without intracranial pathology, propofol decreases $\mathrm{CBF}, \mathrm{CMRO}_{2}$ and increases cerebrovascular resistance. ${ }^{13}$ The $\mathrm{CO}_{2}$ responsiveness of $\mathrm{CBF}$ remains intact during propofol anaesthesia (Craen unpublished data). The effect of propofol on ICP is equivocal. ${ }^{14}$ When used in patients with head trauma, ICP was reduced. ${ }^{15}$ The cardiovascular effects of propofol include systemic hypotension and, as with thiopentone, caution must be used in patients with hypovolaemia and compromised cardiovascular function. ${ }^{16}$ Propofol is not an epileptogenic drug but there are several reports of opisthotonus, myoclonus and other neurological phenomenona following its administration. ${ }^{17}$ These central nervous system effects, although self-limiting, may confuse the clinical picture in a head-injury patient.

\section{MIDAZOLAM}

Midazolam appears to fit the general pattern of benzodiazepines in reducing $\mathrm{CBF}$ and $\mathrm{CMRO}_{2}{ }^{18}$ When midazolam was used as an induction agent in patients with brain tumours, there was no effect on ICP. ${ }^{19}$ Its properties of a short half-life and amnestic effect are useful but when 
compared with thiopentone, midazolam is not as rapidly acting nor predictable. ${ }^{20}$

\section{NITROUS OXIDE}

Nitrous oxide $\left(\mathrm{N}_{2} \mathrm{O}\right)$ will cause an increase in ICP because it is a cerebrovasodilator although the extent of this effect is dependent on the background anaesthetic..$^{21,22}$ In the presence of anaesthetic doses of cerebral vasoconstrictors such as thiopentone or a benzodiazepine, $\mathrm{N}_{2} \mathrm{O}$ may not increase ICP. Other concems include expansion of intracranial air and air in other body cavities. Thus, the widespread use of $\mathrm{N}_{2} \mathrm{O}$ has been questioned.

\section{ISOFLURANE}

Isoflurane at normocapnia increases cerebral blood volume. This increase can be attenuated by moderate hyperventilation prior to the introduction of low-dose isoflurane. ${ }^{23}$ Although, of the currently available inhalational agents, low concentrations of isoflurane are the best to use, isoflurane too, may increase ICP in the presence of brain injury. ${ }^{24}$

\section{FENTANYL}

Fentanyl causes a small decrease in $\mathrm{CBF}$ and $\mathrm{CMRO}_{2}$ provided hypercapnia is prevented. It is a useful agent during induction and tracheal intubation as it lowers ICP yet maintains a stable heart rate and blood pressure. However, a recent study in head-injured patients reported a considerable increase in ICP after fentanyl administration. $^{25}$

\section{SUFENTANIL, ALFENTANIL}

The effects of sufentanil and alfentanil on $\mathrm{CBF}, \mathrm{CMRO}_{2}$ and ICP are controversial and require further investigation. One study suggested that both drugs are associated with considerable increases in CSF pressure making them contraindicated in patients at risk for intracranial hypertension. ${ }^{26}$ However, when patients undergoing craniotomies were anaesthetized with sufentanil, alfentanil or fentanyl with nitrous oxide and hypocapnia, no clinically important difference was found among the agents. ${ }^{27}$ The combination of thiopentone and opioids, particularly sufentanil and alfentanil, can produce a dramatic decrease in MAP and compromise cerebral perfusion. Provided hyperventilation and MAP are maintained, both alfentanil and sufentanil may be appropriate agents to use in the neurosurgical patients. ${ }^{28-30}$ Alfentanil with its rapid onset and short action may be useful for blunting the haemodynamic responses to painful stimuli such as insertion of skull pins or dural incision.

\section{SUCCINYLCHOLINE}

Succinylcholine is unequalled in achieving complete rapid paralysis in patients who require urgent and prompt airway control. Although transient increases in ICP have been noted with its use, they are probably clinically unimportant with an adequate dose of thiopentone..$^{31}$ In the braininjured patients, no increase in CBF or ICP was seen after succinylcholine administration. ${ }^{32}$ With an unstable cervical spine, fasciculations with succinylcholine may result in spinal cord damage. These can be attenuated by prior usage of a small dose of a non-depolarising muscle relaxant.

\section{VECURONIUM, ATRACURIUM}

Neither of these shorter-acting, nondepolarizing muscle relaxants increases ICP and they have little or no effect on the heart rate or blood pressure. ${ }^{33,34}$ Atracurium causes some histamine release which may cause hypotension when given as a large bolus. It also has a metabolite, laudanosine, which although epileptogenic in animals, is probably clinically unimportant in man. ${ }^{35}$

\section{Fluid therapy}

The goal in fluid therapy should be the maintenance of normal cerebral perfusion pressure. Whether crystalloids or colloids are used to resuscitate the patient, it is generally accepted that the head-injured patient should ideally be kept relatively isovolaemic, iso-osmotic, and iso-oncotic. Colloid/blood solutions are more efficacious in rapidvolume resuscitation. The main determinant of water movement across the blood-brain barrier (BBB) is plasma osmolality rather than colloid oncotic pressure ${ }^{36}$ However, in brain injury, with disruption of BBB, water movement is dependent on hydrostatic forces. Although the evidence indicates that isotonic crystalloid solutions do not increase cerebral oedema in brain-injured rabbits, overzealous therapy with both colloids and crystalloids will give rise to oedema formation. ${ }^{37}$ Ringer's lactate is relatively hypoosmolar and therefore large volumes should be avoided.

Glucose-containing solutions are contraindicated as elevated blood glucose concentration has been demonstrated to worsen cerebral ischaemic injury. ${ }^{38}$ One mechanism proposed is that hyperglycaemia increases lactate production via anaerobic metabolism with the subsequent acidosis causing neuronal damage. Hyperglycaemia even without exogenous glucose is frequently observed in severely head-injured patients within $12 \mathrm{hr}$ of injury. ${ }^{39}$

Close monitoring of blood pressure, heart rate, urine output, central venous pressure and serial measurements of haematocrit, serum osmolality and blood glucose should guide appropriate fluid replacement.

\section{Role in patient management}

The anaesthetist may be called upon to attend to a headinjured patient in four areas of the hospital: the Emergency Room, the Radiology Department, the Operating Room and the Intensive Care Unit. At all venues the principles of 
TABLE VI Airway management in head injury

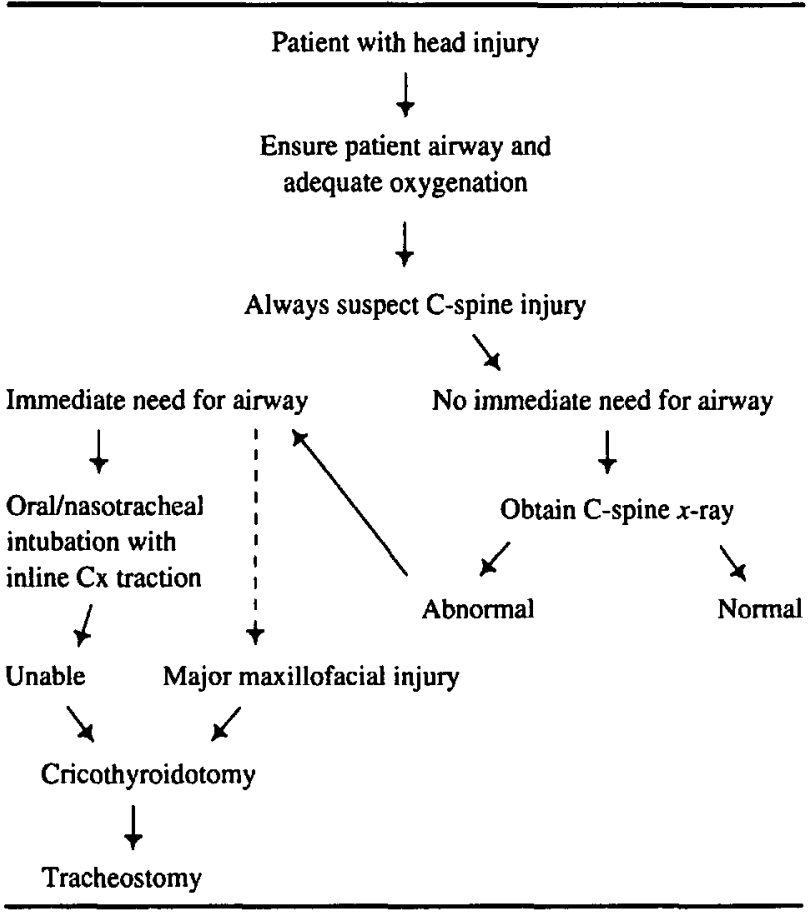

management should be exercised with the same care and control that would be used with a neurosurgical patient in the Operating Room.

\section{Transport}

A recent study revealed a high incidence of secondary insults occurring during intrahospital transport of headinjured patients. ${ }^{40}$ Pretransfer insults were predictive of further insults during and after transport. ${ }^{40}$ If the patient is to be transferred within the hospital or to another hospital, the following are mandatory before transport: a secure airway, adequate resuscitation and stabilization, appropriate monitoring and trained staff.

\section{Induction and intubation}

Evaluation and establishment of the adequacy of the airway, breathing and circulation should be performed before induction of anaesthesia. In $17 \%$ of patients, there will be a cervical spine injury in addition to the head injury. ${ }^{41}$ Table VI outlines a useful protocol in airway management. If awake tracheal intubation is to be performed, direct laryngoscopy is frequently superior to fibreoptic intubation as bloody secretions may obscure the view. Cautious sedation with fentanyl and/or midazolam may be used during assessment and securing the difficult airway.

\section{Maintenance}

The ideal anaesthetic technique for the head-injured
TABLE VII Anaesthesia for head-injured patients

\begin{tabular}{l}
\hline Induction - Equipment check \\
Large bore intravenous \\
Preoxygenation \\
\pm D-tubocurarine \\
Sodium thiopentone \\
Succinylcholine \\
Cricoid pressure \\
Blunt stress of intubation \\
With thiopentone, narcotic \\
\\
Maintenance - Hyperventilation PACO $25-30 \mathrm{mmHg}$ \\
Ensure adequate cerebral $\mathrm{O}_{2}$ delivery \\
Muscle relaxant \\
Narcotic \\
\pm Volatile agent (low dose) \\
\pm N $\mathrm{O}^{-}$ \\
\pm Midazolam \\
Monitoring - ECG, capnography, pulse oximetry \\
BP-arterial line \\
Temperature \\
Central venous pressure \\
Arterial blood gases, osmolarity \\
Blood glucose, haemoglobin \\
Urine output \\
\pm ICP monitoring
\end{tabular}

patient should lower intracranial pressure yet maintain cardiovascular stability thereby increasing cerebral perfusion pressure and ensuring adequate cerebral oxygen delivery. The exact choice of anaesthetic agents is probably less important than their correct use (Table VII). I prefer to use a primary narcotic technique and an amnesticlike midazolam with or without $\mathrm{N}_{2} \mathrm{O}$. In circumstances of a "tight" brain, I avoid $\mathrm{N}_{2} \mathrm{O}$ and volatile agents until the dura is opened and the effects of these agents can be directly observed.

Management of intraoperative hypertension should be discussed with the neurosurgeon. Vasodilators such as nitroglycerin and sodium nitroprusside should be avoided as they can cause an increase in ICP. Instead, betablockers, labetalol, narcotics and low-dose isoflurane in the presence of hypocapnia can be used to control the hypertension and prevent the development of vasogenic oedema.

\section{Emergence}

The prevention of raised ICP during surgery should continue into the recovery period. Extubation is possible in previously awake patients; however, the severely headinjured patient with extracranial trauma may require controlled hyperventilation and ICP control in the Intensive Care Unit. If there is any doubt, it is better to err on the side of safety and keep the trachea intubated and the lungs ventilated. 


\section{Other emergencies}

\section{Emergency clipping of aneurysms}

The anaesthetic management of patients with ruptured intracranial aneurysms has been recently reviewed. ${ }^{42}$ The aims are to control the aneurysm's transmural pressure and ICP while maintaining cerebral oxygen delivery and protecting the brain against focal ischaemia during brain retraction and temporary clipping of the parent artery. Aneurysm surgery is usually elective or urgent and emergency surgery is only required when there is a large intracranial clot.

\section{Anaesthetic management of patient with haematoma in neck}

Haematoma formation in the neck is a complication that follows carotid endarterectomy surgery and is usually precipitated by uncontrolled hypertension and raised venous pressure from coughing and vomiting. The problems facing the anaesthetist are those of a patient who most likely suffers from cardiovascular as well as cerebrovascular disease and who requires urgent surgery, has a compromised airway with distortion of the anatomy by the expanding haematoma and the presence of hypovolaemia in a patient who is still recovering from the previous anaesthetic. Often evacuation of the haematoma can be performed under local anaesthesia but sometimes a general anaesthetic is required. The advisability of awake, sedated, or muscle relaxant-assisted intubation can only be decided at the bedside. The availability of a competent assistant and an array of endotracheal tubes and intubation aids is invaluable.

\section{References}

1 Gelb AW, Manninen PH, Mezon BJ, Durward QJ. The anaesthetist and the head-injured patient. Can Anaesth Soc J 1984; 31: 98-108.

2 Gennarelli TA, Champion HR, Sacco WJ, Copes WS, Alves WM. Mortality of patients with head injury and extracranial injury treated in trauma centers. J Trauma 1989; 29: 1193-202.

3 Miller $J D$. Assessing patients with head injury. Br J Surg 1990; 77: 242.

4 Jenkins A, Teasdale G, Hadley MDM, Macpherson P, Rowan JO. Brain lesions detected by magnetic resonance imaging in mild and severe head injuries. Lancet 1986; 2 : 445-6.

5 Mendelow AD, Teasdale ( 1 . Pathophysiology of head injuries. Br J Surg 1983; 70: 641-50.

6 Rose $J$, Valtonen $S$, Jennett $B$. Avoidable factors contributing to death after head injury. BMJ 1977; 2: 615-8.

7 Grubb RL, Raichle ME, Eichling JO, Ter-Pogossian $M M$. The effects of changes in $\mathrm{PaCO}_{2}$ on cerebral blood volume, blood flow, and vascular mean transit time. Stroke 1974; 5: 630-9.

8 Obrist WD, Langfitt TW, Jaggi JL, Cruz J, Gennarelli $T A$. Cerebral blood flow and metabolism in comatose patients with acute head injury. J Neurosurg 1984; 61: 241-53.

9 Bruce DA, Alavi A, Bilanuik $L$, et al. Diffuse cerebral swelling following head injuries in children: the syndrome of malignant brain oedema. J Neurosurg 1981; 54: 170-8.

10 Marion $D W$, Darby $J$, Yonas $H$. Acute regional cerebral blood flow changes caused by severe head injuries. J Neurosurg 1991; 74: 407-14.

11 Lewelt W, Jenkins LW, Miller JD. Effects of experimental fluid-percussion injury of the brain on cerebrovascular reactivity to hypoxia and to hypercapnia. J Neurosurg 1982; 56: 332-8.

12 Moskopp D, Ries F, Wassmann H, Nadstawek J. Barbiturates in severe head injuries? Neurosurgical Reviews 1991; 14: 195-202.

13 Stephan $H$, Sonntag $H$, Schenk HD, Kohlhausen S. Effect of propofol on cerebral metabolism and on the response of the cerebral circulation to $\mathrm{CO}_{2}$. Anaesthetist 1987; 36: 60-5.

14 Guy J, Gelb AW. The neuropharmacology of propofol. Journal of Drug Development. 1991; 4: 103-5.

15 Herregods L, Verbeke J, Rolly G, Colardyn F. Effect of propofol on elevated intracranial pressure. Preliminary results. Anaesthesia 1988; 43: 107-9.

16 Sebel PS, Lowdon JD. Propofol: a new intravenous anesthetic. Anesthesiology 1989; 71: 260-77.

17 Saunders PRI, Harris MNE. Opisthotonus and other unusual neurological sequelae after outpatient anaesthesia. Anaesthesia 1990; 45: 552-7.

18 Fleischer JE, Milde JH, Moyer TP, Michenfelder JD. Cerebral effects of high-dose midazolam and subsequent reversal with Ro 15-1788 in dogs. Anesthesiology 1988; 68: $234-42$.

19 Giffin JP, Cottrell JE, Shwiry B, Hartung J, Epstein J, Lim $K$. Intracranial pressure, mean arterial pressure, and heart rate following midazolam or thiopental in humans with brain tumors. Anesthesiology 1984; 60:491-4.

20 Reves JG, Fragen RJ, Vinik H, Greenblatt DJ. Midazolam: pharmacology and uses. Anesthesiology $1985 ; 62$ : 310-24.

21 Hansen TD, Warner DS, Todd MM, Vust $L J$. Effects of nitrous oxide and volatile anaesthetics on cerebral blood flow. Br J Anaesth 1989; 63: 290-5.

22 Lam AM, Slee TA, Cooper JO, Bachenberg KL, Mathisen $T L$. Nitrous oxide is a more potent cerebrovasodilator than isoflurane in humans. Jornal of Neurosurgical Anesthesia 1991; 3: A244.

23 Archer DP, Labrecque P, Tyler JL, Meyer E, Trop D. Cerebral blood volume is increased in dogs during admin- 
istration of nitrous oxide or isoflurane. Anesthesiology 1987; 67: 642-8.

24 Scheller MS, Todd MM, Drummond JC, Zornow MH. The intracranial pressure effects of isoflurane and halothane administered following cryogenic brain injury in rabbits. Anesthesiology 1987; 67:507-12.

25 Bailey PL, Sperry RJ, Reichman MV, et al. Both sufentanil and fentanyl increase ICP significantly in resuscitated head trauma patients. Anesthesiology 1991; 75: A198.

26 Marx W, Shah N, Long C, et al. Sufentanil, alfentanil, and fentanyl: impact on cerebrospinal fluid pressure in patients with brain tumors. Joumal of Neurosurgical Anesthesia 1989; 1: 3-7.

27 From RP, Warner DS, Todd MM, Sokoll MD. Anesthesia for craniotomy: a double-blind comparison of alfentanil, fentanyl, and sufentanil. Anesthesiology 1990; 73: 896-904.

28 Herrick IA, Gelb AW, Manninen PH, Reichman H, Lownie $S$. Effects of fentanyl, sufentanil and alfentanil on brain retractor pressure. Anesth Analg 1991; 72: 359-63.

29 Slee TA, Lam AM, Winn HR, Laohaprasit V, Mathisen $T L$. The cerebral hemodynamic and metabolic response to alfentanil in humans. Anesthesiology 1991; 75: A171.

30 Bristow A, Shalev D, Rice B, Lipton JM, Giesecke $A H$. Low-dose synthetic narcotic infusions for cerebral relaxation during craniotomies. Anesth Analg 1987; 66: 413-6.

31 Crosby $G$, Todd $M M$. On neuroanesthesia, intracranial pressure, and a dead horse. Journal of Neurosurgical Anesthesiology 1990; 2: 143-5.

32 Kovanik WD, Lam AM, Slee TA, Mathisen TL. The effect of succinylcholine on intracranial pressure, cerebral blood flow velocity \& electroencephalogram in patients with neurologic disorders. Journal of Neurosurgical Anesthesiology 1991; 3: A245.

33 Rosa G, Sanfilippo M, Vilardi V, Orfei P, Gasparetto $A$. Effects of vecuronium bromide on intracranial pressure and cerebral perfusion pressure. Br J Anaesth 1986; 58 : 437-40.

34 Rosa G, Orfei P, Sanfilippo M, Vilardi V, Gasparetto $A$. The effects of atracurium besylate (Tracrium) on intracranial pressure and cerebral perfusion pressure. Anesth Analg 1986; 65: 381-4.

35 Chapple DJ, Miller AA, Ward JB, Wheatley PL. Cardiovascular and neurological effects of laudanosine. $\mathrm{Br} J$ Anaesth 1987; 59: 218-25.

36 Zornow MH, Todd MM, Moore SS. The acute cerebral effects of changes in plasma osmolality and oncotic pressure. Anesthesiology 1987; 67: 936-41.

37 Zornow MH, Scheller MS, Todd MM, Moore S. Acute cerebral effects of isotonic crystalloid and colloid solutions following cryogenic brain injury in the rabbit. Anesthesiology 1988; 69: 180-4.
38 Lanier WL, Strangland KJ, Scheithauer BW, Milde JH, Michenfelder JD. The effects of dextrose infusion and head position on neurologic outcome after complete cerebral ischemia in primates: examination of a model. Anesthesiology 1987; 66: 39-48.

39 De Salles AAF, Muizelaar JP, Young HF. Hyperglycemia, cerebrospinal fluid lactic acidosis and cerebral blood flow in severely head injured patients. Neurosurgery 1987; 21: 45-50.

40 Andrews PJD, Piper IR, Dearden NM, Miller JD. Secondary insults during intrahospital transport of head injured patients. Lancet 1990; 335: 327-30.

41 Mackenzie CF, Shin B, Fisher $R$, Cowley RA. Four year mortality of trauma victims admitted directly from the accident by helicopter. Anesthesiology 1982; 57: A96.

42 Herrick $I A, G e l b A W$. Anesthesia for intracranial aneurysm surgery. Journal of Clinical Anesthesia 1992; 4: 73-85. 


\section{Conduite anesthésique lors d'urgences neurochirurgicales}

Rosemary A. Craen MB BS FFARACS, Adrian W. Gelb MB ChB FRCPC
TABLEAU I Urgences neurochirurgicales

\begin{aligned} \hline Lésions : & \\ Trauma & - Peau, muscles \\ & - Os \\ & - Vaisseaux \\ & - Cerveau \\ Effet de masse & - Sang \\ & - Pus \\ & - Tumeur \\ & - LCR \end{aligned}

Occlusion vasculaire

\section{TABLEAU II Lésion cérébrale primaire}

\begin{tabular}{l|l}
\hline Amnésie & \\
Choc direct & Un continuum \\
Contusion & \\
Lacération & \\
Lésion axonale diffuse \\
Mort instantanée
\end{tabular}

TABLEAU III Causes de lésions cérébrales secondaires

\section{Physiopathologie du traumatisme crânien}

Le traumatisme au cerveau se produit en deux phases. Au moment de l'impact, il y a un degré variable de blessures primaires au cerveau. Ceci est habituellement irréversible. Par la suite, des événements secondaires s'enchaînent et vont conduire à l'aggravation du traumatisme et souvent à la mort. Actuellement, nous avons des mesures préventives mais pas de mesures thérapeutiques pour la lésion cérébrale primaire. Tout notre traitement est orienté vers la lésion secondaire. Le choc initial au cerveau s'inscrit dans un continuum (Tableau II). Les blessures légères ont tendance à se limiter au cortex alors que les plus sérieuses vont toucher les structures plus profondes, incluant le tronc cérébral. Même la blessure la plus légère peut s'associer à un dommage cérébral ; les patients qui sont intacts sur le plan neurologique peuvent faire preuve de lésions corticales à la tomographie par résonnance magnétique. ${ }^{4}$

Les lésions secondaires au cerveau (Tableau III), lorsque surimposées au traumatisme primaire, ont un impact important sur le sort des patients avec traumatisme crânien. ${ }^{5}$ Si le patient arrive à l'hôpital vivant, dès lors, théoriquement, le traitement ou la prévention des lésions secondaires devraient prévenir le décès. Dans une revue

\begin{tabular}{ll}
\hline Systémiques & Intracrâniennes \\
\hline Hypoxémie & Hématome \\
Hypotension & Oedème \\
Anémie & Hydrocéphalie \\
Hypercarbie & Épilepsie \\
Hyperthermie & \\
\hline
\end{tabular}

des causes de décès évitables chez les traumatisés crâniens qui parlaient après le traumatisme, $26 \%$ avaient de l'obstruction respiratoire, $22 \%$ de l'hypotension et $17 \%$ des convulsions mal contrôlées. ${ }^{6} \mathrm{~L}$ 'anesthésiste a l'habileté et les connaissances de la physiologie et de la pharmacologie nécessaires pour apporter une contribution importante au bien-être de ces patients.

\section{Facteurs qui influencent la pression intra-crânienne}

L'espace intra-crânien peut être considéré comme un contenant rigide de volume à peu près constant qui contient le cerveau (85\%), du sang (5\%) et le liquide céphalorachidien (LCR) (10\%). Lors du traumatisme crânien, le volume intra-crânien est le plus souvent augmenté par l'apparition d'hématomes ou d'oedème. Cette augmenta- 
TABLEAU IV Traitement de l'hypertension intracrânienne

\begin{tabular}{lll}
\hline Immédiat & Court terme & Moyen terme \\
\hline Hyperventilation & Mannitol & Chirurgie \\
Thiopental & Furosémide & Hypothermie \\
Musculo-relaxants & Tête levée & Restriction liquidienne \\
Drainage externe de LCR & $\downarrow$ T.A. & \\
Autres sédatifs & & \\
\hline
\end{tabular}

tion de volume d'un des composants peut être compensée par une réduction de volume des autres éléments. Initialement, le LCR est déplacé hors du crâne dans l'espace sous-arachnoïdien rachidien distensible. Une absorbtion de liquide céphalo-rachidien amène un certain degré additionnel de compensation. Le sang se déplace aussi des veines et sinus intra-crâniens vers les veines jugulaires et les veines épidurales rachidiennes. Finalement, le cerveau est éloigné de la masse, soit d'un côté vers l'autre, ou d'un compartiment à l'autre à travers la tente du cerveau. Ces « mécanismes tampons » fonctionnent bien au début et la pression intra-crânienne change très peu. Éventuellement, les mécanismes compensatoires se dérèglent. À mesure que la PIC augmente, une toute petite augmentation du volume intra-crânien conduira à une augmentation importante de PIC. L'importance clinique de cette augmentation de PIC est double. D'abord, la pression de perfusion cérébrale ( $\mathrm{PPC})$. qui est la différence entre la pression artérielle moyenne (PAM) et la PIC diminue jusqu'à un point critique où l'ischémie apparaît. Deuxièmement, les déplacements du cerveau qui ont compensé les changements de volume vont comprimer les structures vasculaires, ce qui amène de l'ischémie et la mort cérébrale.

Les augmentations de pression intra-crânienne peuvent être traitées de plusieurs façons (Tableau IV). $\mathrm{La} \mathrm{PaCO}_{2}$ est un modulateur physiologique puissant du débit sanguin cérébral (DSC) et du volume sanguin cérébral (VSC). Le volume sanguin change d'environ $0,04 \mathrm{ml} \cdot 100 \mathrm{~g}^{-1} \mathrm{de}$ tissu perfusé pour chaque $\mathrm{mmHg}$ de variation de $\mathrm{PaCO}_{2}$ artérielle dans un écart de 20 à $80 \mathrm{mmHg}{ }^{7}$ Dans le cerveau moyen $(1,400 \mathrm{~g})$, ceci représente 0,56 $\mathrm{ml} \cdot \mathrm{mmHg}^{-1}$ de $\mathrm{PaCO}_{2}$. Une réduction de $\mathrm{PaCO}_{2}$ de 45 $\mathrm{mmHg}$ à $25 \mathrm{mmHg}$ va de là réduire le volume sanguin cérébral d'environ $11 \mathrm{ml}$. Cette petite baisse de volume peut devenir importante si le patient se retrouve sur le point d'inflexion de la courbe de compliance intracrânienne. L'hyperventilation aiguë a un effet rapide, ce qui en fait le premier choix dans le traitement d'une augmentation de PIC. L'hyperventilation, avec sa tendance à la vasoconstriction, peut avoir un effet néfaste en réduisant le débit sanguin cérébral. On retrouve souvent une diminution du débit sanguin et de la consommation d'oxygène cérébral chez les traumatisés crâniens, et ces patients ne retireront probablement pas de bénéfice de la
TABLEAU V Effet des agents sur la PIC

\begin{tabular}{lll}
\hline Diminution & Pas de changement & Augmentation \\
\hline Thiopental & Vécuronium & Kétamine \\
Propofol & Atracurium & Succinylcholine \\
Benzodiazépines & Pancuronium & d-Tubocurarine \\
Narcotiques & $\mathrm{N}_{2} \mathrm{O} \pm$ anesth. suppl. & Protoxyde d'azote \\
Dropéridol & Labétatol & Isoflurane \\
& $\beta$-bloqueurs & Halothane \\
& & Nitroglycérine \\
& & Nitroprussiate \\
& & Hydralazine \\
\hline
\end{tabular}

vasoconstriction additionnelle. ${ }^{8}$ Par contre, chez certains patients, surtout les enfants, il se produit un phénomène d'hyperémie aiguë entraînant une augmentation de pression intra-crânienne et un gonflement diffus du cerveau, qui pourra répondre à l'hyperventilation. ${ }^{8,9}$ Malheureusement, on ne peut prédire à partir des signes cliniques ou des tomographies axiales, chez quel patient on retrouvera un débit sanguin cérébral à valeur critique. ${ }^{10} \mathrm{La}$ saturation veineuse cérébrale en oxygène peut être utile pour déterminer le niveau optimal d'hypocapnie puisqu'un débit sanguin cérébral global inadéquat produira une différence artério-veineuse en oxygène importante. ${ }^{8}$

Le traumatisme cérébral nuit à la réponse cérébrovasculaire normale aux variations de pression artérielle, $\mathrm{d}^{\prime} \mathrm{O}_{2}$, et de $\mathrm{CO}_{2}{ }^{1{ }^{11}}$ L'autorégulation est la première touchée, suivie de la réponse à l'hypoxie, et enfin il y a perte de réactivité au $\mathrm{CO}_{2}{ }^{1}{ }^{1}$ Les régions touchées par une auto-régulation défectueuse verront leur débit sanguin cérébral varier de façon passive selon le rapport PAM/ PPC. Ainsi des pressions normalement accompagnées d'aucun changement de DSC pourront produire des niveaux critiques d'ischémie ou des augmentations dramatiques de pression intra-crânienne. Malheureusement, la réactivité au $\mathrm{CO}_{2}$ est abolie tardivement et sa perte confirme un mauvais pronostic. ${ }^{8}$

\section{Effets des médicaments}

L'effet des substances pharmacologiques sur la pression intra-crânienne est décrit dans le Tableau V.

\section{THIOPENTAL}

Le thiopental est toujours l'agent d'induction de choix chez le patient traumatisé crânien parce qu'il produit une réduction, proportionnelle à la dose, du débit sanguin cérébral et de la pression intra-crânienne. Cependant, la dose d'induction doit être titrée en doses faibles pour éviter une diminution catastrophique de la pression artérielle chez les patients hypovolémiques. Son efficacité comme agent protecteur cérébral dans le traumatisme crânien n'est pas encore établie. ${ }^{12}$ 


\section{PROPOFOL}

Chez les patients sans pathologie intra-crânienne, le propofol diminue le débit sanguin cérébral, la consommation d'oxygène cérébrale et augmente la résistance vasculaire cérébrale. ${ }^{13}$ La réponse au $\mathrm{CO}_{2}$ de la circulation cérébrale demeure intacte pendant l'anesthésie au propofol (Craen, données non publiées). L'effet du propofol sur la pression intra-crânienne demeure équivoque. ${ }^{14}$ Lorsqu'il est utilisé chez les patients avec traumatisme cérébral, la pression intra-crânienne diminue. ${ }^{15}$ Les effets cardiovasculaires du propofol comprennent une hypotension systémique et, comme pour le thiopental, il faut être prudent lorsqu'on l'utilise chez les patients hypovolémiques ou avec fonction cardiovasculaire compromise ${ }^{16}$ Le propofol n'est pas une substance épileptogénique, mais plusieurs communications mentionnent de l'opisthotonus, des myoclonies, et d'autres phénomènes neurologiques à la suite de son administration. ${ }^{17} \mathrm{Ces}$ effets nerveux centraux, même s'ils sont auto-limitants, peuvent être des distracteurs dans le tableau clinique d'un patient avec traumatisme cérébral.

\section{MIDAZOLAM}

Le midazolam semble se conformer au tableau général d'activité des benzodiazépines, en réduisant le débit sanguin cérébral et la consommation d'oxygène cérébrale. ${ }^{18}$ Lorsqu'on a utilisé le midazolam comme agent d'induction chez les patients avec tumeur cérébrale, on n'a pas noté d'effets sur la pression intra-crânienne. ${ }^{19}$ Le midazolam a une demie-vie courte et un effet amnésiant utiles, mais lorsque comparé au thiopental il n'agit pas aussi rapidement ni de façon aussi prévisible. ${ }^{20}$

\section{PROTOXYDE D'AZOTE}

Le protoxyde d'azote $\left(\mathrm{N}_{2} \mathrm{O}\right)$ va créer une augmentation de pression intra-crânienne puisqu'il est un vasodilatateur cérébral, même si la portée de cet effet va dépendre de l'agent anesthésique de base. ${ }^{21,22}$ En présence de doses anesthésiques de vaso-constricteurs cérébraux tels le thiopental ou une benzodiazépine, le protoxyde d'azote peut ne pas augmenter la pression intra-crânienne. Il ne faut pas oublier non plus l'expansion de l'air intra-crânien et de l'air dans les autres cavités du corps. Pour ces raisons, on remet en question l'utilisation du protoxyde d'azote.

\section{ISOFLURANE}

L'isoflurane en normocapnie va augmenter le volume sanguin cérébral. Cette augmentation peut être diminuée par une hyperventilation modérée établie avant l'introduction d'isoflurane à faible dose. ${ }^{23}$ Même s'il est l'agent de choix à faible concentration parmi les agents d'inhalation disponibles actuellement, l'isoflurane peut lui aussi augmenter la pression intra-crânienne en présence de traumatisme cérébral.

\section{FENTANYL}

Le fentanyl crée une faible diminution de débit sanguin cérébral et de la consommation d'oxygène cérébrale à la condition qu'il n'y ait pas d'hypercapnie. Ce narcotique est un agent utile pendant l'induction et l'intubation puisqu'il diminue la pression intra-crânienne, tout en maintenant une fréquence cardiaque et une pression artérielle stables. Cependant un travail récent chez des patients traumatisés crâniens mentionne une importante diminution de pression intra-crânienne après l'administration de fentanyl. ${ }^{25}$

\section{SUFENTANIL, ALFENTANIL}

Les effets du sufentanil et de l'alfentanil sur le débit sanguin cérébral, la consommation d'oxygène cérébral et la pression intra-crânienne sont controversés et devraient faire l'objet de plus de travaux de recherche. Une étude suggère que les deux substances semblent amener des augmentations importantes de pression de liquide céphalorachidien, ce qui les contre-indique chez les malades à risque d'hypertension intra-crânienne. ${ }^{26}$ Cependant, chez les malades soumis à une crâniotomie sous sufentanil, alfentanil ou fentanyl avec du protoxyde d'azote et une hypocapnie, on n'a pas retrouvé de différence cliniquement importante entre ces agents. ${ }^{27}$ La combinaison de thiopental et d'opiacés, en particulier le sufentanil et l'alfentanil, peut amener des diminutions importantes de pression artérielle moyenne et mettre en péril la perfusion cérébrale. Autant l'alfentanil que le sufentanil seront des agents appropriés pour l'anesthésie de patients neurochirurgicaux, dans la mesure où l'on assurera une hyperventilation et un maintien de la pression artérielle moyenne. ${ }^{28-30} \mathrm{~L}$ 'alfentanil, avec son début d'action rapide et de courte durée, pourra être utile pour amortir les réponses hémodynamiques aux stimulis douloureux tels que l'insertion des supports de tête et les incisions de dure-mère.

\section{SUCCINYLCHOLINE}

La succinylcholine n'a pas son égal pour amener une paralysie complète et rapide chez les patients qui ont besoin d'un contrôle rapide des voies aériennes en urgence. Même si l'on a pu noter des augmentations transitoires de PIC à l'usage, elles sont probablement peu importantes sur le plan clinique lorsqu'on utilise une dose adéquate de thiopental. ${ }^{31}$ Chez les traumatisés crâniens, on n'a pas noté d'augmentation de débit sanguin cérébral ou de la pression intra-crânienne après l'administration de succinylcholine. ${ }^{32}$ Lorsque la colonne cervicale est 
instable, les fasciculations causées par la succinylcholine peuvent causer des blessures à la moëlle. Celles-ci peuvent être atténuées en utilisant une dose préalable de musculorelaxant non dépolarisant.

\section{VÉCURONIUM, ATRACURIUM}

Aucun des ces musculorelaxants non dépolarisant n'augmente la pression intra-crânienne et ils ont peu ou pas d'effet sur la fréquence cardiaque et/ou la pression artérielle. ${ }^{33.34} \mathrm{~L}$ 'atracurium amène une libération d'histamine qui peut provoquer de l'hypotension lorsque donné en bolus important. L'atracurium a aussi un métabolite épileptogène chez l'animal, le laudanosine, mais ceci n'a probablement pas d'importance clinique chez l'homme. ${ }^{35}$

\section{Thérapie liquidienne}

Le but de la thérapie liquidienne devrait être le maintien d'une pression de perfusion cérébrale normale. Que l'on utilise des cristalloïdes ou des colloïdes pour réanimer les patients, on va accepter généralement que le patient traumatisé crânien devrait idéalement être maintenu en isovolémie, avec une pression osmotique et oncotique tout aussi normales. Les combinaisons de sang et de colloïdes sont plus efficaces pour produire une réanimation volémique rapide. La déterminant principal des mouvements de l'eau à travers la barrière hémo-encéphalique est l'osmolarité plasmatique plutôt que la pression oncotique. ${ }^{36}$ Cependant, dans les traumatismes crâniens, il y a atteinte de la barrière hémo-encéphalique, et les mouvements de l'eau vont dépendre des forces hydrostatiques. Même si l'on n'a pas rêuussi à démontrer que les solutions cristallö̈des isotoniques augmentent l'oedème cérébral chez des lapins avec contusion cérébrale, une thérapie excessive autant avec les collö̈des que les cristallö̈des pourra provoquer la formation d'oedème.$^{37} \mathrm{La}$ solution de Ringer au lactate est relativement hypo-osmolaire et pour cette raison on devrait éviter de donner des volumes importants de cette solution.

Les solutions glucosées sont contre-indiquées puisqu'on a démontré qu'une glycémie élevée va aggraver une lésion cérébrale d'origine ischémique. ${ }^{38}$ On a proposé comme mécanisme que l'hyperglycémie augmente la production de lactate dans le liquide céphalo-rachidien à partir d'un métabolisme anaérobique, avec comme conséquence une acidose et des dommages aux neurones. On note souvent une hyperglycémie sans apport exogène de glucose chez les patients avec traumatisme cérébral sévère dans les premières 12 heures du traumatisme. ${ }^{39}$

Une surveillance serrée de la pression artérielle, de la fréquence cardiaque, du débit urinaire, de la tension veineuse centrale, de l'hématocrite sériée, de l'osmolarité sérique et de la glycémie devraient orienter la thérapie liquidienne appropriée.
TABLEAU VI Protection des voies aériennes dans le traumatisme crânien

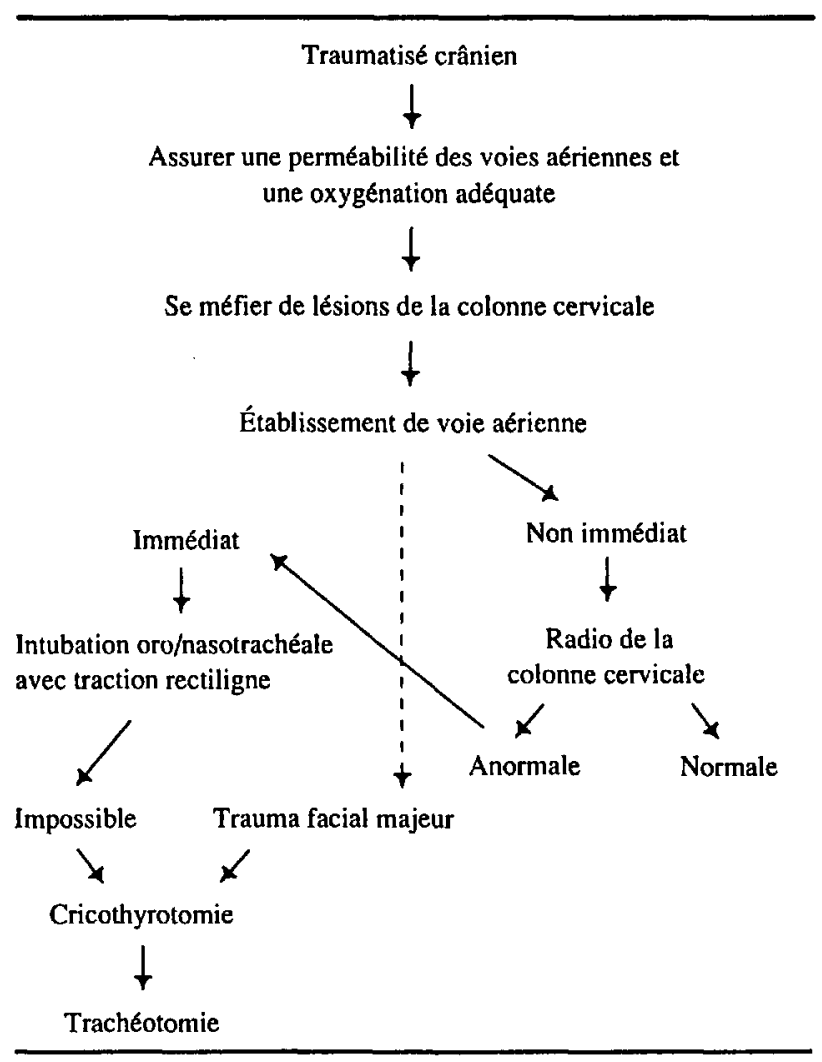

Rôle de l'anesthésiste dans le soin du malade

On peut faire appel à l'anesthésiste auprès d'un traumatisé crânien dans quatre secteurs de l'hôpital: la salle d'urgence, le département de radiologie, la salle d'opération et l'unité de soins intensifs. À tous ces endroits les principes de conduite devraient être observés avec le même soin et contrôle que lors d'une anesthésie neurochirurgicale en salle d'opération.

\section{Transport}

Un travail récent a montré une incidence élevée de blessures secondaires durant le transport intrahospitalier des traumatisés intra-crâniens. ${ }^{40}$ Les dommages constatés avant les transferts ont été prédicteurs de dommages subséquents pendant et après le transport. ${ }^{40} \mathrm{Si}$ le patient doit être transféré à l'intérieur de l'hôpital ou vers un autre hôpital, il faut s'assurer des choses suivantes avant le transport: la protection de voies aériennes, une réanimation et une stabilisation adéquates, une surveillance appropriée et du personnel expérimenté.

\section{Induction et intubation}

Il faut avant l'induction s'assurer de la qualité de la protection des voies aériennes, de celle de la respiration et de la circulation. Dix-sept pour cent des patients auront 
TABLEAU VII Anesthésie du traumatisé crânien

\begin{tabular}{|c|c|}
\hline Induction & $\begin{array}{l}\text { - Vérifier l'appareillage } \\
\text { - Voie intraveineuse de gros calibre } \\
\text { - Préoxygénation } \\
\text { - Précurarisation ( } \pm \text { ) } \\
\text { - Thiopental } \\
\text { - Succinylcholine } \\
\text { - Pression sur cricoïde } \\
\text { - Diminuer réaction à l'intubation (thiopental, narcotiques) }\end{array}$ \\
\hline Entretien & $\begin{array}{l}\text { - Hyperventilation }\left(\mathrm{PaCO}_{2} 25-30 \mathrm{mmHg}\right) \\
\text { - Apport cérébral d' } \mathrm{O}_{2} \text { adéquat } \\
\text { - Relaxation musculaire } \\
\text { - Narcotiques } \\
- \pm \text { volatils (faibles doses) } \\
- \pm \mathrm{N}_{2} \mathrm{O} \\
- \pm \text { Midazolam }\end{array}$ \\
\hline Monitoring & $\begin{array}{l}\text { - ECG, capnographe, saturomètre } \\
\text { - T.A. : ligne artérielle } \\
\text { - Température } \\
\text { - TVC } \\
\text { - Gaz sanguins, osmolarité } \\
\text { - Glycémie, Hb } \\
\text { - Débit urinaire } \\
\text { - } \pm \text { mesure de la PIC }\end{array}$ \\
\hline
\end{tabular}

aussi un traumatisme de la colonne cervicale ajouté à leur traumatisme crânien. ${ }^{41}$ Le tableau VI décrit un protocole utile pour la protection des voies aériennes. La laryngoscopie directe sera préférable souvent à l'intubation par fibroscopie lorsqu'on envisage une intubation éveillée, puisque souvent des sécrétions sanglantes vont obscurcir le champ de vision. On pourra utiliser une sédation prudente au fentanyl et/ou au midazolam pendant l'évaluation et l'établissement d'une voie aérienne.

\section{Maintien}

La technique idéale d'anesthésie du patient traumatisé crânien devra diminuer la pression intra-crânienne, tout en maintenant une stabilité cardiovasculaire, ce qui amène une augmentation de la pression de perfusion cérébrale et assure un apport d'oxygène adéquat au cerveau. Lè choix précis de l'agent anesthésique est probablement moins important que son usage approprié (Tableau VII). Je préfère utiliser une technique à base de narcotiques associés à un amnésiant comme le midazolam, avec ou sans protoxyde d'azote. Lorsqu'il y a possibilité de cerveau comprimé, j'évite l'utilisation de $\mathrm{N}_{2} \mathrm{O}$ et des volatils jusqu'à ce que la dure-mère soit ouverte et que l'on puisse observer l'effet de ces agents par observation directe.

Le traitement de l'hypertension intra-opératoire fera objet de discussion avec le neurochirurgien. Des vasodilatateurs tels la nitroglycérine et le nitroprussiate de sodium devront être évités puisqu'ils peuvent augmenter la pres- sion intra-crânienne. On peut utiliser des $\beta$-bloqueurs, du labétalol, des narcotiques et de l'isoflurane à faible dose et sous hypocapnie, pour contrôler l'hypertension et prévenir l'apparition d'oedème vasogénique.

\section{Recouvrement}

Il faut continuer à prévenir l'augmentation de pression intra-crânienne pendant la période de recouvrement. On peut penser à extuber les patients déjà conscients avant la chirurgie, mais les traumatisés crâniens sérieusement atteints, porteurs de traumatismes extra-crâniens, pourront nécessiter une hyperventilation contrôlée et un contrôle de la pression intra-crânienne dans l'unité de soins intensifs. Lorsqu'il y a un doute quelconque, il est préférable de s'assurer une marge de sécurité et conserver les patients intubés et les poumons ventilés.

\section{Autres urgences}

\section{Clampage d'urgence d'anévrysmes cérébraux}

On a revu récemment la conduite anesthésique chez les patients avec anévrysme intra-cérébral rupturé. ${ }^{42}$ Les objectifs sont de contrôler la pression transmurale des anévrysmes et la pression intra-crânienne, tout en maintenant un apport d'oxygène au cerveau, et de protéger le cerveau contre l'ischémie focale pendant la rétraction du cerveau et le clampage temporaire de l'artère nourricière. La chirurgie pour anévrysme est habituellement élective ou urgente et la chirurgie immédiate est requise seulement lorsqu'il y a un hématome intra-cérébral important.

\section{Conduite anesthésique du patient avec hématome cervical}

L'hématome cervical est une complication associée à l'endartérectomie carotidienne et sera consécutif à une hypertension non-contrôlée et à une augmentation de pression veineuse associée à la toux et au vomissement. Les problèmes que doit envisager l'anesthésiste sont les suivants: une chirurgie d'urgence chez un patient qui souffre probablement de problèmes cardio-vasculaires et cérébrovasculaires, une voie aérienne compromise et déformée par l'hématome en expansion, et la présence d'hypovolémie chez un patient qui récupère d'une anesthésie récente. L'hématome sera souvent évacué sous anesthésie locale mais à l'occasion, il faut procéder à une anesthésie générale. Le choix entre l'intubation éveillée sous sédation ou par le biais d'un musculorelaxant ne peut être décidé qu'au chevet. On peut difficilement se passer d'assistance experte et d'un choix de matériel d'intubation varié.

\section{Références \\ (Voir page R33)}

